\title{
Diagnostic and therapeutic approaches to optic disc pit maculopathy in children
}

\author{
Dimitrios Kalogeropoulos ${ }^{1,2}$, Ioannis Asproudis ${ }^{1}$, Soon Wai Ch'ng ${ }^{2}$, Arijit Mitra ${ }^{2}$, Ash Sharma ${ }^{2}$, \\ Konstantinos Katsikatsos ${ }^{1}$, Christopher Asproudis ${ }^{1}$ and Chris Kalogeropoulos ${ }^{1}$ \\ ${ }^{1}$ Department of Ophthalmology, Faculty of Medicine, School of Health Sciences, University of Ioannina, Greece \\ ${ }^{2}$ Birmingham Midlands Eye Centre, Sandwell and West Birmingham Hospitals NHS Trust, Dudley Road, \\ Birmingham, UK
}

\begin{abstract}
Background: Optic disc pit (ODP) is a rare congenital defect of the optic disc that can lead to maculopathy and gradual visual impairment. This review summarizes our current knowledge on the diagnostic and therapeutic approaches to ODP maculopathy (ODP-M) in children.

Methods: A thorough literature search was performed using the PubMed/MEDLINE database from 1960 to 2020. An additional search was conducted using Google Scholar for completeness.

Results: ODP-M is characterized by the accumulation of subretinal and/or intraretinal fluid. The exact pathogenetic mechanisms are not fully understood, and the origin of the fluid remains unknown. Although ODP-M is more likely to occur during the third or fourth decade of life, cases of children with serous retinal detachment have been recorded. Early diagnosis of ODP-M and prompt, appropriate management are crucial, particularly in patients of amblyogenic age. In adults, ODP-M may resolve spontaneously, but most cases require surgical intervention to prevent permanent loss of vision. However, the fact that ODP-M may spontaneously resolve in children cannot be ignored. Various surgical methods have been described, including pars plana vitrectomy (PPV) combined with various techniques, including laser photocoagulation, intravitreal gas injection, and macular buckling.

Conclusions: PPV remains the mainstay surgical approach for ODP-M. However, ODP-M may differ between children and adults. Children constitute a unique population of patients that require a different and probably more tailor-made approach. Detailed clinical examination, combined with a thorough analysis of retinal imaging, may improve our understanding of the background and pathophysiology of the disease and eventually provide us with new insights into the management of ODP-M in the pediatric population.
\end{abstract}

\section{KEY WORDS}

congenital anomalies, optic disc pit, optic disc pit maculopathy, retinal imaging, surgical treatment, pars plana vitrectomy

\section{INTRODUCTION}

An optic disc pit (ODP) is a cavitary abnormality of the optic nerve head similar to optic disc coloboma, morning glory, and extrapapillary cavitation [1]. It is typically a congenital disorder, but it is also associated with other ophthalmic disorders, such as myopia or glaucoma [2-4]. It is a rare entity, with an estimated prevalence of 2 in approximately 10,000 of the general population, with no gender predilection $[5,6]$. Although mostly unilateral,

Correspondence: Dimitrios Kalogeropoulos, Faculty of Medicine, School of Health Sciences, Department of Ophthalmology, University of Ioannina. Stavros Niarchos Ave., 45500, Ioannina, Greece. E-mail: dkalog1990@gmail.com. ORCID iD: https://orcid.org/0000-0001-6404-5409

How to cite this article: Kalogeropoulos D, Asproudis I, Ch'ng SW, Mitra A, Sharma A, Katsikatsos K, Asproudis C, Kalogeropoulos C. Diagnostic and therapeutic approaches to optic disc pit maculopathy in children. Med Hypothesis Discov Innov Optom.2021 Spring; 2(1): 24-35. DOI: https://doi.org/10.51329/mehdioptometry122

Received: 17 April 2021 Accepted: 01 June 2021

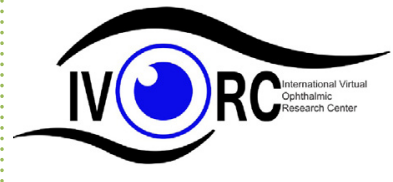

Copyright (C) Author(s). This is an open-access article distributed under the terms of the Creative Commons Attribution-NonCommercial 4.0 International License (http://creativecommons.org/licenses/by-nc/4.0/) which permits copy and redistribute the material just in noncommercial usages, provided the original work is properly cited. (c) (i) (5) 
bilateral ODP occurs in up to $15 \%$ of cases $[1,7]$. Most cases are sporadic, but in families with more than one affected member, autosomal inheritance has also been reported [8-10].

Formation of ODP has not been linked to any specific genetic profile to date. In most patients, the condition is asymptomatic and may be detected incidentally during routine ophthalmological assessments. However, it may sometimes present with irreversible visual field defects, such as enlarged blind spots or paracentral arcuate scotomas [11]. Moreover, ODP has been linked to macular changes, such as serous detachment, cystic degeneration, and degenerative pigmentary changes that can lead to a decline in central visual acuity (VA) [1114]. In $25-75 \%$ of patients with ODP, macular detachment and/or retinoschisis occur at some stage of their lifetime, which leads to a condition termed ODP-maculopathy (ODP-M) [1]. Although ODP-M is more likely to occur during the third or fourth decade of life [15], cases of children with serous retinal detachment have been reported [7, 16-20]. It has been estimated that spontaneous resolution with good visual outcomes occurs in approximately $25 \%$ of cases [21]. However, coexisting macular detachment can be accompanied by lamellar or full-thickness macular holes, cystoid changes, and retinal pigment epithelium atrophy, causing an irreversible visual loss with a Snellen VA of 20/200 or worse, particularly in longstanding cases [22, 23].

There are several case reports and case series of ODP-M in children in the available literature, but only a few population-based studies have been reported [24]. However, children constitute a unique population that requires a different management style than adults. This review aimed to summarize current knowledge on the diagnostic and therapeutic approaches to ODP-M in children.

\section{METHODS}

A thorough literature search was performed in the PubMed/MEDLINE database. An additional search was conducted using Google Scholar. The following keywords were used in the searches: congenital anomalies, optic disc pit, optic disc pit maculopathy, retinal imaging, surgical treatment, and pars plana vitrectomy. We reviewed papers published between 1960 and 2020, focusing on studies published after 2000, and using mostly those published after 2010. Only references in English were included. Additionally, the patients' archives from our unit were the source of figures used in this manuscript to support the importance of clinical, imaging, and laboratory findings in the diagnostic workup.

\section{RESULTS}

ODP-M is related to the accumulation of subretinal and/or intraretinal fluid. The exact pathogenetic mechanisms are not fully understood, and the origin of the fluid remains unknown [1]. Although ODP-M is more likely to occur during the third or fourth decade of life, cases of children with serous retinal detachment have been recorded [7, 15-20]. The clinical signs and symptoms of ODP-M are summarized in Table 1. In adults, ODP-M may resolve spontaneously, but most cases require surgical intervention to prevent permanent loss of vision [25]. Various surgical methods have been described, including pars plana vitrectomy (PPV) (combined with various techniques), laser photocoagulation, intravitreal gas injection, and macular buckling [1,26-30]. The characteristics and main findings of the studies involving pediatric patients with ODP-M are summarized in Table 2.

\section{DISCUSSION}

Most children with ODP are asymptomatic, whereas those that develop ODP-M report a recent gradual visual deterioration, which is consistent with the presence of serous macular elevations [31]. The Snellen VA can range from $20 / 25$ to counting fingers, depending on the severity and duration of maculopathy. Disturbances in color vision and visual fields may also be present [31,32]. On fundal examination (Figure 1), ODP appears as a hypopigmented, round, or oval excavation near the optic disc margin, most commonly in the inferior temporal quadrant of the disc. The pit is centrally located in approximately $10-20 \%$ of cases [33]. ODP may involve from one-eighth to one-quarter of the optic disc, and fine interlacing glial tissue fills the cavity to some extent [14, 15, 33]. Central retinal vessels can be normally observed, but in some cases, a vessel can extend into the depth of the pit, disappearing and appearing again on the other side of the ODP. Cilioretinal and optociliary vessels can also pass through the pit [14]. The amount of intraretinal fluid and therefore the degree of neurosensory retinal detachment and macular elevation are not related to the pit size and may vary significantly among individuals $[11,33]$. These features are usually expected between the supratemporal and inferotemporal arcades, but can potentially develop beyond this anatomical area. Macular and pigmentary changes may arise as complications in persistent ODP-M cases [34]. 
Table 1. Clinical signs and symptoms of ODP and ODP-M [11, 14, 15, 31-34]

\begin{tabular}{|l|}
\hline Symptoms \\
\hline Thost individuals with ODP are asymptomatic. \\
\hline VA can range from Snellen $20 / 25$ to CF depending on the severity and duration of maculopathy. \\
\hline Disorders in color vision and visual fields may also appear. \\
\hline Fundoscopic signs \\
\hline ODP appears as a hypopigmented, round or oval excavation near the optic disc margin. \\
\hline Most commonly, ODP is located in the inferior temporal quadrant of the disc. \\
\hline A central location of the pit may be observed in approximately $10-20 \%$ of cases. \\
\hline ODP may involve one-eighth to one-quarter of the optic disc, and delicate interlacing glial tissue fills the cavity up to some extend. \\
\hline Central retinal vessels are normally observed. \\
\hline In some cases, a vessel can go extend into the depth of the pit, disappear, and reappear again on the other side of the ODP. \\
\hline Cilioretinal and optociliary vessels can also course to and from the pit. \\
\hline $\begin{array}{l}\text { The amount of intraretinal fluid, and therefore the degree of neurosensory retinal detachment and serous macular elevation, are not } \\
\text { related to the pit size and may vary significantly. }\end{array}$ \\
\hline Macular and pigmentary alterations may arise as complications in persistent ODP-M cases. \\
\hline Abbriation
\end{tabular}

Abbreviations: ODP, optic disc pit; ODP-M, optic disc pit maculopathy; VA, visual acuity; CF, counting fingers.

Table 2. Characteristics and main findings of studies involving pediatric patients with optic disc pit maculopathy (ODP-M)

\begin{tabular}{|c|c|c|c|c|c|c|c|}
\hline First author/Year & Type of study & Cases & Laterality & Clinical findings & $\begin{array}{l}\text { Imaging } \\
\text { findings }\end{array}$ & Intervention & Final outcome \\
\hline $\begin{array}{l}\text { Kalogeropoulos et al., } 2020 \\
{[16]}\end{array}$ & Case series & 1 & Unilateral & $\begin{array}{l}\text { ODP in the } \\
\text { temporal aspect } \\
\text { of the ONH with } \\
\text { contiguous IRF. }\end{array}$ & IRF & Observation & Spontaneous resolution \\
\hline Benatti et al., 2021 [63] & Case report & 1 & Unilateral & ODP & ODP-M & Observation & Spontaneous resolution \\
\hline Kovacova et al., 2018 [67] & $\begin{array}{l}\text { Retrospective } \\
\text { study }\end{array}$ & 2 & Unilateral & $\begin{array}{l}\text { ODP at the tem- } \\
\text { poral aspect of the } \\
\text { ONH. }\end{array}$ & $\begin{array}{l}\text { Retinoschisis } \\
\text { SRF in one } \\
\text { eye. }\end{array}$ & PPV with C3F8. & $\begin{array}{l}\text { BCVA improvement and resolu- } \\
\text { tion of SRF. }\end{array}$ \\
\hline Akça Bayar et al., 2017 [19] & Case report & 1 & Unilateral & $\begin{array}{l}\text { ODP at the tem- } \\
\text { poral aspect of the } \\
\text { ONH. }\end{array}$ & $\begin{array}{l}\text { Retinoschisis } \\
\text { and fluid under } \\
\text { the ILM. }\end{array}$ & Observation & $\begin{array}{l}\text { BCVA improvement and spon- } \\
\text { taneous resolution of fluid. }\end{array}$ \\
\hline Mete et al, 2017 [68] & Case series & 1 & Unilateral & ODP & $\begin{array}{l}\text { Serous macular } \\
\text { detachment } \\
\text { and SRF. }\end{array}$ & $\begin{array}{l}\text { Vitrectomy with } \\
\text { ILM peeling and } \\
\text { SF6. }\end{array}$ & $\begin{array}{l}\text { BCVA improvement and com- } \\
\text { plete macular reattachment. }\end{array}$ \\
\hline Ozdek et al., 2017 [51] & Case series & 1 & Unilateral & ODP & $\begin{array}{l}\text { Serous macular } \\
\text { detachment } \\
\text { and SRF. }\end{array}$ & $\begin{array}{l}\text { PPV with ILM } \\
\text { peeling and SF6. } \\
\text { Secondary, autolo- } \\
\text { gous fibrin used to } \\
\text { seal optic pit and } \\
\text { aspiration of SRF. }\end{array}$ & $\begin{array}{l}\text { BCVA improvement and } \\
\text { macular reattachment. }\end{array}$ \\
\hline Maertz et al., 2017 [58] & $\begin{array}{l}\text { Retrospective } \\
\text { observational } \\
\text { study }\end{array}$ & 2 & Bilateral & $\begin{array}{l}\text { Left eyes: temporal } \\
\text { ODP, BCVA } \\
\text { compromised. } \\
\text { Right eyes: central/ } \\
\text { temporal pit-like } \\
\text { depression of the } \\
\text { papilla. }\end{array}$ & $\begin{array}{l}\text { Left eyes: } \\
\text { macular de- } \\
\text { tachment and } \\
\text { retinoschisis } \\
\text { and vitreoreti- } \\
\text { nal traction in } \\
\text { optic disc. }\end{array}$ & $\begin{array}{l}\text { Observation, history } \\
\text { of previous PPV } \\
\text { with ILM peeling } \\
\text { and endolaser } \\
\text { coagulation in } 1 \text { eye } \\
\text { with ODP. }\end{array}$ & $\begin{array}{l}\text { BCVA improvement in the eyes } \\
\text { with ODP, stable in the eyes } \\
\text { with a pit-like depression. }\end{array}$ \\
\hline Rossi et al., 2017 [8] & Case report & 1 & Bilateral & $\begin{array}{l}\text { ODP at the tem- } \\
\text { poral aspect of the } \\
\text { ONH. }\end{array}$ & $\begin{array}{l}\text { Serous macular } \\
\text { detachment. }\end{array}$ & Observation & N/A \\
\hline Yokoi et al., 2016 [59] & $\begin{array}{l}\text { Retrospective } \\
\text { review }\end{array}$ & 4 & $\begin{array}{l}3 \text { unilateral } \\
1 \text { bilateral }\end{array}$ & $\begin{array}{l}\text { Three of four pa- } \\
\text { tients have ODP at } \\
\text { the temporal aspect } \\
\text { of the ONH. One } \\
\text { of four patients } \\
\text { presents a colo- } \\
\text { bomatous disc with } \\
\text { ODPs temporally } \\
\text { and inferiorly. }\end{array}$ & $\begin{array}{l}\text { Three of } \\
\text { four patients } \\
\text { present schisis } \\
\text { and RD. }\end{array}$ & $\begin{array}{l}\text { PPV in three of four } \\
\text { patients. Observa- } \\
\text { tion in one patient } \\
\text { with colobomatous } \\
\text { optic disc. }\end{array}$ & $\begin{array}{l}\text { Postoperative improvement } \\
\text { of BCVA. Post-op attachment } \\
\text { of the retina in two of three } \\
\text { patients and SRF recession in } \\
\text { the other patient. No VA data } \\
\text { for the patient with coloboma- } \\
\text { tous disc. }\end{array}$ \\
\hline
\end{tabular}




\begin{tabular}{|c|c|c|c|c|c|c|c|}
\hline Rayat et al., 2015 [60] & $\begin{array}{l}\text { Retrospective } \\
\text { review }\end{array}$ & 7 & Unilateral & $\begin{array}{l}\text { ODP at the tem- } \\
\text { poral aspect of the } \\
\text { ONH. }\end{array}$ & $\begin{array}{l}\text { SRF in the } \\
\text { macula }\end{array}$ & $\begin{array}{l}\text { PPV }(7 / 7) ; \text { ILM } \\
\text { peeling }(1 / 7) ; \\
\text { temporal optic disk } \\
\text { endolaser }(2 / 7) ; \\
\text { C3F8 }(2 / 7) \text {; and } \\
\text { SF6 }(5 / 7) \text {. }\end{array}$ & $\begin{array}{l}\text { BCVA improvement }(6 / 7) \text {, } \\
\text { BCVA slightly worsened in one } \\
\text { patient with PPV, and C3F8 } \\
\text { attached fovea }(7 / 7) .\end{array}$ \\
\hline Lei et al., 2015 [61] & Case series & 2 & Unilateral & $\begin{array}{l}\text { ODP at the tem- } \\
\text { poral aspect of the } \\
\text { ONH. }\end{array}$ & $\begin{array}{l}\text { Inner retinal } \\
\text { schisis and } \\
\text { outer layer } \\
\text { detachment at } \\
\text { the macula. }\end{array}$ & $\begin{array}{l}\text { PPV with C3F8. } \\
\text { Posterior pole laser } \\
\text { photocoagulation. }\end{array}$ & $\begin{array}{l}\text { BCVA improvement, fluid reso- } \\
\text { lution, and retinal reattachment. }\end{array}$ \\
\hline Akiyama et al., 2014 [69] & Case series & 2 & Unilateral & $\begin{array}{l}\text { ODP at the tem- } \\
\text { poral aspect of the } \\
\text { ONH. }\end{array}$ & $\begin{array}{l}\text { Serous macular } \\
\text { detachment. }\end{array}$ & SF6 gas injections & $\begin{array}{l}\text { BCVA improvement and } \\
\text { macular reattachment. }\end{array}$ \\
\hline Sanghi et al., 2014 [70] & Case series & 4 & Unilateral & ODP & $\begin{array}{l}\text { Retinal schisis } \\
\text { and outer layer } \\
\text { detachment } \\
(3 / 4) . \text { Only } \\
\text { outer layer } \\
\text { detachment } \\
(1 / 4) .\end{array}$ & $\begin{array}{l}\text { PPV, C3F8, and } \\
\text { laser photocoagula- } \\
\text { tion at the temporal } \\
\text { edge of ODP. }\end{array}$ & $\begin{array}{l}\text { BCVA improvement and resolu- } \\
\text { tion of retinal schisis, and outer } \\
\text { layer detachment }(3 / 4) \text {. BCVA } \\
\text { stable and retinal schisis. Outer } \\
\text { layer detachment persistent } \\
(1 / 4) \text {. }\end{array}$ \\
\hline Marticorena et al., 2013 [71] & Case report & 1 & Unilateral & $\begin{array}{l}\text { ODP at the tem- } \\
\text { poral aspect of the } \\
\text { ONH. }\end{array}$ & $\begin{array}{l}\text { Serous macular } \\
\text { detachment. } \\
\text { Retinal schisis } \\
\text { from the disc } \\
\text { to the macular } \\
\text { area. }\end{array}$ & $\begin{array}{l}\text { PPV, SF6, and diode } \\
\text { laser photocoagu- } \\
\text { lation. } \\
\text { Secondary ILM } \\
\text { peeling and diode } \\
\text { endolaser. }\end{array}$ & $\begin{array}{l}\text { BCVA improvement after sec- } \\
\text { ond operation with resolution } \\
\text { of SRF and IRF. }\end{array}$ \\
\hline Ozkaya et al., 2013 [64] & Case report & 1 & Bilateral & $\begin{array}{l}\text { ODP in the } \\
\text { temporal aspect of } \\
\text { the ONH. }\end{array}$ & $\begin{array}{l}\text { Loss of retinal } \\
\text { tissue and } \\
\text { no presence } \\
\text { of SRF. De- } \\
\text { creased RNFL } \\
\text { thickness } \\
\text { temporal to } \\
\text { optic nerve. }\end{array}$ & Observation & $\begin{array}{l}\text { No changes in BCVA and } \\
\text { RNFL. }\end{array}$ \\
\hline Shukla et al., 2012 [56] & Case series & 2 & Unilateral & $\begin{array}{l}\text { ODP in the } \\
\text { temporal aspect of } \\
\text { the ONH. }\end{array}$ & $\begin{array}{l}\text { Macular schisis } \\
\text { with a large } \\
\text { central outer } \\
\text { retinal defect. }\end{array}$ & $\begin{array}{l}\text { PPV, ILM peeling, } \\
\text { and peripapillary } \\
\text { endolaser photoco- } \\
\text { agulation. }\end{array}$ & $\begin{array}{l}\text { Macular holes closed. BCVA } \\
\text { improvement. Outer retinal } \\
\text { detachment resolution. }\end{array}$ \\
\hline Rizzo et al., 2012 [57] & Case series & 1 & Unilateral & $\begin{array}{l}\text { ODP in the tem- } \\
\text { poral aspect of the } \\
\text { ONH. Serous RD. }\end{array}$ & $\begin{array}{l}\text { Macular hole, } \\
\text { and SRF. }\end{array}$ & $\begin{array}{l}\text { PPV, ILM peeling, } \\
\text { and endolaser. } \\
\text { photocoagulation } \\
\text { temporally to the } \\
\text { ONH. }\end{array}$ & $\begin{array}{l}\text { Macular hole closed. } \\
\text { BCVA improvement. }\end{array}$ \\
\hline Hirakata et al., 2012 [72] & Case series & 2 & Unilateral & $\begin{array}{l}\text { ODP inferotempo- } \\
\text { ral of the ONH. }\end{array}$ & $\begin{array}{l}\text { Outer layer } \\
\text { schisis-like and } \\
\text { inner layer sep- } \\
\text { aration, RD. }\end{array}$ & $\begin{array}{l}\text { PPV with no laser or } \\
\text { gas injection. }\end{array}$ & $\begin{array}{l}\text { Complete retinal reattachment. } \\
\text { BCVA improvement. }\end{array}$ \\
\hline Rii et al., 2013 [25] & Case series & 4 & Unilateral & $\begin{array}{l}\text { ODP-M after } \\
\text { trauma. }\end{array}$ & N/A & $\begin{array}{l}\text { PPV with gas } \\
\text { tamponade. }\end{array}$ & N/A \\
\hline Hiraoka et al., 2010 [62] & $\begin{array}{l}\text { Retrospective } \\
\text { study }\end{array}$ & 1 & Unilateral & $\begin{array}{l}\text { ODP inferotem- } \\
\text { poral to the ONH } \\
\text { with serous macu- } \\
\text { lar detachment. }\end{array}$ & $\begin{array}{l}\text { Outer and in- } \\
\text { ner layer retina } \\
\text { schisis. }\end{array}$ & $\begin{array}{l}\text { PPV without laser } \\
\text { photocoagulation. }\end{array}$ & $\begin{array}{l}\text { BCVA improvement. Reso- } \\
\text { lution of the detachment and } \\
\text { schisis. }\end{array}$ \\
\hline Georgalas et al., $2010[17]$ & Case report & 1 & Unilateral & $\begin{array}{l}\text { ODP at the tem- } \\
\text { poral aspect of the } \\
\text { ONH. }\end{array}$ & $\begin{array}{l}\text { IRF and SRF } \\
\text { in the macula. }\end{array}$ & $\begin{array}{l}\text { PPV, ILM peeling, } \\
\text { air tamponade } \\
\text { without laser photo- } \\
\text { coagulation. }\end{array}$ & $\begin{array}{l}\text { BCVA improvement and resolu- } \\
\text { tion of the IRF and SRF, and } \\
\text { macula re-attachment. }\end{array}$ \\
\hline Imamura et al., 2010 [73] & Case series & 4 & Unilateral & ODP with SRF. & $\begin{array}{l}\text { SRF commu- } \\
\text { nicating with } \\
\text { pit. Outer } \\
\text { nuclear layer, } \\
\text { inner nuclear } \\
\text { layer fluid. }\end{array}$ & Observation & $\mathrm{N} / \mathrm{A}$ \\
\hline Chiu et al., 2006 [74] & Case report & 1 & Unilateral & $\begin{array}{l}\text { ODP at the tem- } \\
\text { poral aspect of the } \\
\text { ONH. }\end{array}$ & $\begin{array}{l}\text { Posterior pole } \\
\text { serous RD, } \\
\text { outer layer } \\
\text { detachment. } \\
\text { Schisi like } \\
\text { cavity. }\end{array}$ & $\begin{array}{l}\text { PPV, SF6, and laser } \\
\text { photocoagulation at } \\
\text { the temporal margin } \\
\text { of the ODP. }\end{array}$ & $\begin{array}{l}\text { BCVA improvement } \\
\text { Absorption of SRF (no } \\
\text { resolution). }\end{array}$ \\
\hline
\end{tabular}




\begin{tabular}{|c|c|c|c|c|c|c|c|}
\hline Spaide et al., 2006 [75] & Case report & 1 & Unilateral & $\begin{array}{l}\text { ODP at the tem- } \\
\text { poral aspect of the } \\
\text { ONH. }\end{array}$ & $\begin{array}{l}\text { Serous macular } \\
\text { detachment. }\end{array}$ & $\begin{array}{l}\text { PPV and a needle } \\
\text { retinal penetration } \\
\text { creating an alterna- } \\
\text { tive outflow path } \\
\text { for SRF. }\end{array}$ & $\begin{array}{l}\text { BCVA improvement. Absorp- } \\
\text { tion of SRF (no resolution). }\end{array}$ \\
\hline Ishikawa et al., 2005 [76] & Case report & 1 & Unilateral & $\begin{array}{l}\text { ODP at the tem- } \\
\text { poral aspect of the } \\
\text { ONH. }\end{array}$ & $\begin{array}{l}\text { Schisis-like } \\
\text { separation of } \\
\text { the sensory } \\
\text { retina. Serous } \\
\text { macular } \\
\text { detachment. }\end{array}$ & $\begin{array}{l}\text { Laser photocoagula- } \\
\text { tion and vitrectomy. }\end{array}$ & $\begin{array}{l}\text { BCVA improvement and SRF } \\
\text { resolution. }\end{array}$ \\
\hline Hirakata et al., 2005 [77] & Case report & 1 & Unilateral & $\begin{array}{l}\text { ODP at the tem- } \\
\text { poral aspect of the } \\
\text { ONH. }\end{array}$ & $\begin{array}{l}\text { Macular } \\
\text { detachment } \\
\text { and separation } \\
\text { of the inner } \\
\text { retinal layers } \\
\text { that appeared } \\
\text { to connect } \\
\text { with the optic } \\
\text { disc. }\end{array}$ & PPV with SF6. & $\begin{array}{l}\text { BCVA improvement and com- } \\
\text { plete retinal reattachment. }\end{array}$ \\
\hline Bakri et al., 2004 [78] & Case report & 1 & Unilateral & $\begin{array}{l}\text { ODP at the tem- } \\
\text { poral aspect of the } \\
\text { ONH. }\end{array}$ & $\begin{array}{l}\text { Serous macular } \\
\text { detachment. }\end{array}$ & $\begin{array}{l}\text { PPV, full-thickness } \\
\text { retinotomy, photo- } \\
\text { coagulation spots at } \\
\text { the temporal aspect } \\
\text { of optic nerve, and } \\
\text { on the retinotomy. } \\
\text { PPV, endolaser } \\
\text { photocoagulation } \\
360^{\circ} \text { around the } \\
\text { optic nerve, and } \\
\text { C3F8 gas. }\end{array}$ & $\begin{array}{l}\text { BCVA improvement. } \\
\text { Retinal reattachment. }\end{array}$ \\
\hline Meyer et al., 2004 [79] & Case report & 1 & Unilateral & $\begin{array}{l}\text { ODP at the infero- } \\
\text { temporal aspect of } \\
\text { ONH. }\end{array}$ & $\begin{array}{l}\text { Serous macular } \\
\text { detachment } \\
\text { with outer } \\
\text { layer detach- } \\
\text { ment and a } \\
\text { schisis-like } \\
\text { cavity. }\end{array}$ & $\mathrm{N} / \mathrm{A}$ & N/A \\
\hline Brodsky et al., 2003 [65] & Case report & 1 & Unilateral & $\begin{array}{l}\text { ODP at the tem- } \\
\text { poral aspect of the } \\
\text { ONH. }\end{array}$ & $\begin{array}{l}\text { Serous macular } \\
\text { detachment. }\end{array}$ & Observation & $\begin{array}{l}\text { BCVA improvement and serous } \\
\text { macular detachment resolved } \\
\text { spontaneously. }\end{array}$ \\
\hline Yuen et al., 2002 [20] & Case report & 1 & Unilateral & $\begin{array}{l}\text { ODP at the tem- } \\
\text { poral aspect of the } \\
\text { ONH. }\end{array}$ & $\begin{array}{l}\text { Serous macular } \\
\text { detachment. }\end{array}$ & Observation & $\begin{array}{l}\text { BCVA improvement and serous } \\
\text { macular detachment resolved } \\
\text { spontaneously. }\end{array}$ \\
\hline $\begin{array}{l}\text { Theodossiadis et al., } 1999 \\
\text { [23] }\end{array}$ & Case series & 2 & Unilateral & ODP & $\begin{array}{l}\text { Case } 1 . \\
\text { Schisis-like } \\
\text { separation of } \\
\text { the internal } \\
\text { layers of the } \\
\text { retina and cyst } \\
\text { formation in } \\
\text { foveola. } \\
\text { Case } 2 . \\
\text { Schisis-like } \\
\text { separation, } \\
\text { confluent cysts } \\
\text { and outer layer } \\
\text { detachment. }\end{array}$ & $\begin{array}{l}\text { Scleral macular } \\
\text { buckling. }\end{array}$ & $\begin{array}{l}\text { BCVA improvement. Flattened } \\
\text { macula with no presence of fluid } \\
\text { in the retina or external to the } \\
\text { neurosensory retina. }\end{array}$ \\
\hline
\end{tabular}

Abbreviation: ODP, Optic disc pit; ONH, optic nerve head; IRF, Intraretinal fluid; SRF, Subretinal fluid; PPV, Pars plana vitrectomy; C3F8, perfluoropropane gas; ILM, Internal limiting membrane; RD, retinal detachment; BCVA, Best-corrected visual acuity; SF6, sulfur hexafluoride gas; N/A, Not available; VA, Visual acuity; RNFL, Retinal nerve fiber layer.

In children, ODP has been associated with rare diseases that occur as a result of developmental disorders and are also linked with other abnormalities of the optic disc. These clinical entities include basal encephalocele, bilateral renal hypoplasia, Aicardi syndrome, Alagille syndrome (JAG1 mutation), and midline neurological developmental malformation [35-39]. Despite being a well-recognized clinical entity, the precise origin and pathogenesis of the intra- and sub-retinal fluid in ODP-M has not yet been clarified, and there are no obvious triggering factors [1]. It has been hypothesized that ODP-M may be related to posterior vitreous detachment (PVD) [40, 41], but this is questionable, as ODP-M has also been reported in children with no evidence of vitreous liquefaction $[25,40]$. Regardless of the fluid origin, a generally accepted series of events occur during 
the development of ODP-M $[1,33,40,42]$. First, fluid derived from the ODP leads to a schisis-like inner retinal separation that causes a mild cecocentral scotoma. Then, an outer retinal detachment occurs as a result of subretinal dissection of the fluid $[43,44]$. The discovery of several hypothetical pathogenetic mechanisms has led to the development of various concepts for managing this rare condition $[1,34]$.

\section{Patient assessment and the importance of multimodal imaging}

The patient's complaints and clinical features must be considered in order to develop a thorough diagnostic approach. Careful slit-lamp examination and indirect fundoscopy are crucial for detecting abnormalities of the optic disc (Table 1). Ophthalmic examination is also largely assisted by available imaging techniques. Previous studies have thoroughly described the role of retinal imaging in the management of ODP and ODP-M [1, 21, 45]. Imaging tools include fundus photography, fundus autofluorescence, optical coherence tomography (OCT), fluorescein, and indocyanine green angiography. Appropriate and timely use of each modality can be extremely helpful not only in making a diagnosis, but also in making therapeutic decisions and in monitoring patients [1, $16,21,34,46]$. Jeng-Miller et al. [47] highlighted the contribution of OCT in a detailed in vivo evaluation of the anatomic abnormalities of the optic disc and their associated pathologies, suggesting that it can provide new insights into the management of these conditions in children.

Exploring the potential of OCT features in the prediction of anatomical and functional outcomes is particularly interesting, as various patterns of subretinal and intraretinal fluid have been described in ODP-M. Roy et al. [45] investigated 32 eyes of patients in the age range of 7-54 years with ODP-M and found that $46 \%$ of eyes presented with subretinal and multilayered intraretinal fluid, $26 \%$ with subretinal and outer retinal layer fluid, $21 \%$ with intraretinal fluid only, and only $4 \%$ with subretinal fluid alone. The findings of this study suggest that fluid first seeps into the outer retinal layer before involving the other layers. The percentages reported by Roy et al. are in broad agreement with those reported by Steel et al. [48], who found that the pattern of fluid distribution on OCT was predictive of outcome. More specifically, patients with subretinal and multilayer fluid had worse visual and anatomical outcomes than those with subretinal fluid and outer retinal layer fluid only. Additionally, patients with fluid extending beyond the vascular arcades had worse outcomes than those in whom the extent of the fluid was less. One possible explanation for these two negative prognostic factors is that they are both associated with a longer-duration disease [48].

Overall, a thorough study and analysis of different imaging modalities (Figures 2, 3, 4) can contribute to improved understanding of the anatomical associations and therefore the pathogenesis of the disease, thereby facilitating the development of novel treatments and potentially better visual outcomes.

\section{Management of ODP-M}

\section{General concept of the therapeutic approach}

Conservative treatment of ODP-M was initially proposed, as $25 \%$ of cases would resolve spontaneously. However, considering the natural course of ODP-M in combination with the persistence of fluid implies the need for a more aggressive and efficient approach, and several surgical methods have been adopted to prevent visual deterioration and to improve the final outcome [1]. PPV (23- or 25-gauge) remains the mainstay of ODP-M treatment and is usually combined with laser treatment, gas tamponade, and/or internal limiting membrane (ILM) peeling [1]. Intravitreal gas tamponade with or without laser application has also been proposed as an alternative therapeutic option, because pneumatic displacement can cause reattachment of the macula and improve VA [26]. Theodossiadis et al. introduced the macular buckling technique for the treatment of ODP-M [27-30]. The anatomical and functional outcomes of macular buckling rely on the pathophysiology of the disorder, and the hypothesis that the origin of the subretinal fluid may be derived from both vitreous and cerebrospinal fluid. Although the results of this technique are impressive, it is considered a difficult technique, with a steep learning curve. Several other surgical procedures have been employed for the treatment of ODP-M, including inner retinal fenestration, autologous fibrin use, and glial tissue removal [49-53]. Recently, Theodossiadis et al. [46] summarized the latest treatments for ODP-M, mainly focusing on covering and filling the ODP with an ILM inverted flap. This procedure is successful if the subretinal fluid originates from the vitreous cavity. On the other hand, filling the ODP with a rolled ILM-flap, autologous scleral tissue, or human amniotic membrane can provide favorable anatomical results. It appears that both these techniques may lead to promising outcomes when combined with PPV. However, there are only a limited number of available reports regarding ODP covering and filling techniques [46]. Therefore, vitreoretinal surgeons should consider several parameters and possible complications when using this technique in the treatment of ODP-M. 


\section{Special considerations in the pediatric population}

The clinical course of ODP-M in children seems to differ from that of the typical form of the disease in adults. Ophthalmologists must monitor and record any changes in the VA of children, because they are at risk of amblyopia and subsequently lifelong visual disability. This condition may also indirectly affect children's education and school performance [54]. Early diagnosis of ODP-M and prompt, appropriate management are crucial, particularly in patients of amblyogenic age.

A retrospective study by Rii et al. [25] evaluated fundoscopic and OCT findings in children and adults with ODP-M. The results of their study showed that ODP-M in childhood occurred most commonly after blunt ocular trauma in eyes with strong vitreous adhesion to the margin of the optic disc. Adults presented with more varied symptoms, including visual impairment, metamorphopsia, micropsia, and myodesopsia, whereas visual impairment was the only symptom in children. This may be because children are not able to describe visual impairment as accurately as adults [25].

Several studies have reported that PPV combined with ILM peeling (to relieve vitreoretinal traction), with or without laser photocoagulation, yields promising outcomes in children [17, 53-62]. Laser photocoagulation of the temporal margin of the optic disc aims to prevent further vitreous fluid from entering the subretinal/intraretinal space [57].

Ozdek and Ozdemir described the use of autologous fibrin for the treatment of persistent ODP-M. The anatomical success of their approach was attributed to the presumed autologous fibrin-enhanced local tissue response that prevented fluid passage from the subarachnoid space to the subretinal space [51]. An older study by Theodossiadis et al. [23] described cyst formation as a phenomenon that accompanied ODP-associated macular detachment in five cases in their series, of which two were children. Their study showed that the macular scleral buckle procedure was an effective approach, as cyst formation gradually decreased and finally disappeared after the surgery [23].

However, the fact that ODP-M may spontaneously resolve in children cannot be ignored [19, 20, 63-65]. Benatti et al. [63] reported a characteristic case of a 12-year-old child with ODP-M that spontaneously resolved after a 6-year follow-up, suggesting that functional and morphological evaluation over time could be critical for determining the optimal management of ODP-M, particularly in children for whom the conservative approach appears to be a reasonable alternative to surgery. A single-center study by Bloch et al. [66] investigated the natural history of ODP-M in a cohort of 87 patients and found that many patients maintained good long-term visual acuity with gradual improvement of the condition, without surgical intervention. Their findings suggested that there may be evidence supporting a delay in surgical intervention until visual deterioration is recorded, due to the potential stability or spontaneous resolution of subretinal fluid, the high rate of reoperation, and the long-term positive outcomes of deferred intervention (Table 2) [66].

The strengths of our review include that we have summarized the clinical and surgical experience of the collaborating centers in combination with our previous research activity in ODP-M. The main limitations are related to the relatively small number of studies in the pediatric population. Further studies with emphasis on the structurefunction relationships of ODP and other congenital optic disc anomalies will expand our knowledge and improve our clinical practice related to diagnosis, management, and prognosis of this rare condition. Most importantly, it is highly recommended that the risks and benefits of all available therapeutic options be thoroughly discussed with the family to ensure that the best approach will be offered. There is an obvious need for prospective studies on this rare condition to explore the validity of further prognostic factors and the response to various therapeutic approaches.

\section{CONCLUSIONS}

Although ODP-M typically affects adults during the third or fourth decade of life, it can also occur during childhood. ODP-M constitutes an underdiagnosed clinical entity that can mimic other causes of subretinal fluid. This condition may also indirectly affect children's education and school performance. Careful clinical examination and detailed imaging analysis are the cornerstones of establishing a diagnosis and avoiding misinterpretation. Prompt, appropriate management is crucial, particularly in patients of amblyogenic age. Several studies have reported that PPV combined with ILM peeling (to relieve vitreoretinal traction), with or without laser photocoagulation, yields promising outcomes in children. Spontaneous resolution of the subretinal fluid with a subsequent improvement in VA has been reported, but the majority of cases have a poor visual prognosis if left untreated. Awareness and early identification of ODP-M are important for improving disease management and, consequently, the final visual outcome. Defining specific prognostic factors may contribute to the management of ODP-M. Decision-making is more complicated and demanding in the pediatric population. Ideally, more prospective or randomized controlled trials are necessary to evaluate the diagnostic and therapeutic approaches to pediatric ODP-M. 


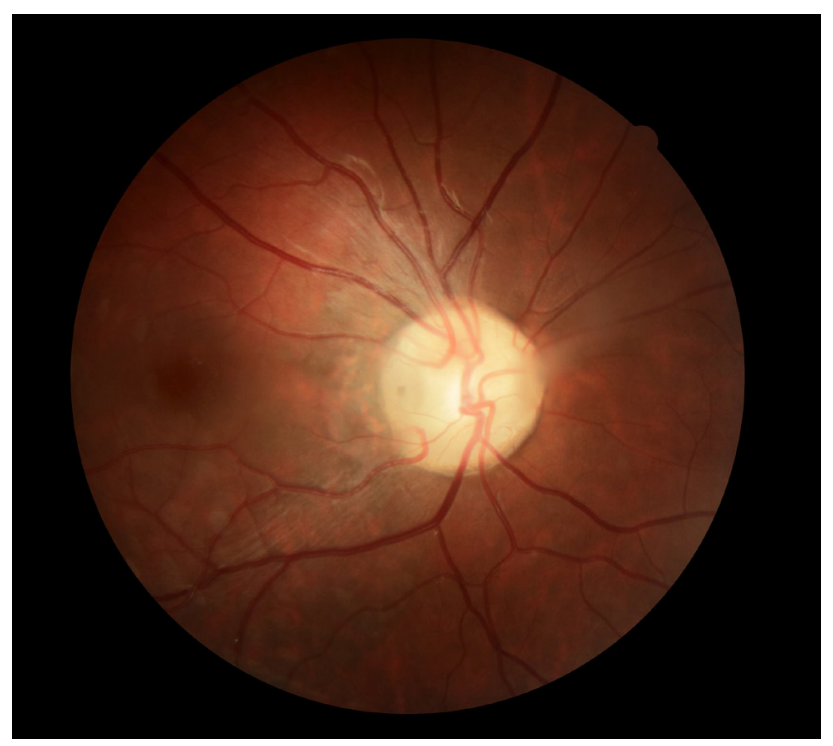

Figure 1. Fundus photograph of a 16-year-old female with a unilateral (right eye) optic disc pit, presenting as a grayish oval excavation near the margin of the optic disc (CR-2 AF Digital Non-Mydriatic Retinal Camera, Canon USA, Inc., Melville, NY, USA).

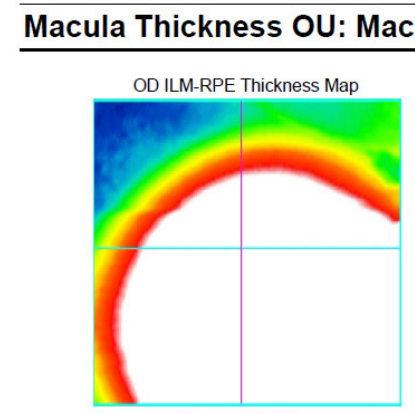

Fovea: 248,63

OD OCT Fundus

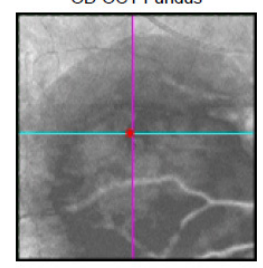

OD ILM-RPE Thickness

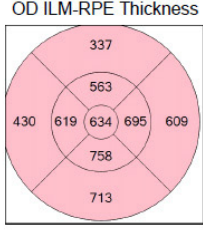

Cube $512 \times 128$

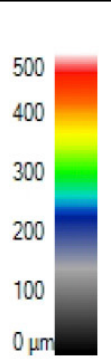

(i)
OD

OS ILM-RPE Thickness Map

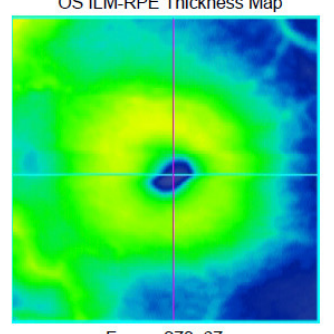

Fovea: 270,67

OS ILM-RPE Thickness OS OCT Fundus

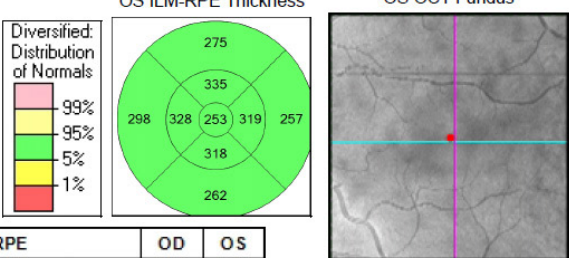

BScan: 67
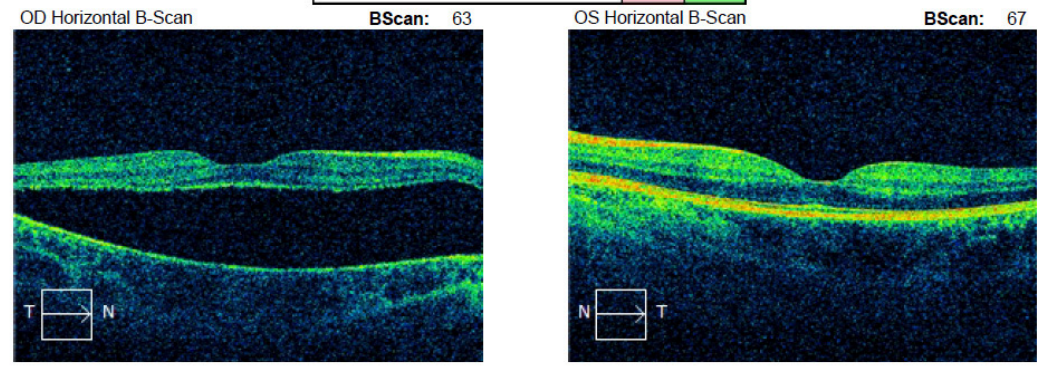

Figure 2. Bilateral optical coherence tomography (OCT) of the same patient as in Figure 1. OCT and macula thickness analysis show optic disc pit maculopathy (ODP-M) with subretinal fluid in the right eye in comparison with the left eye (the Cirrus" HD-OCT Model 400 [Carl Zeiss Meditech, Dublin, CA]). 


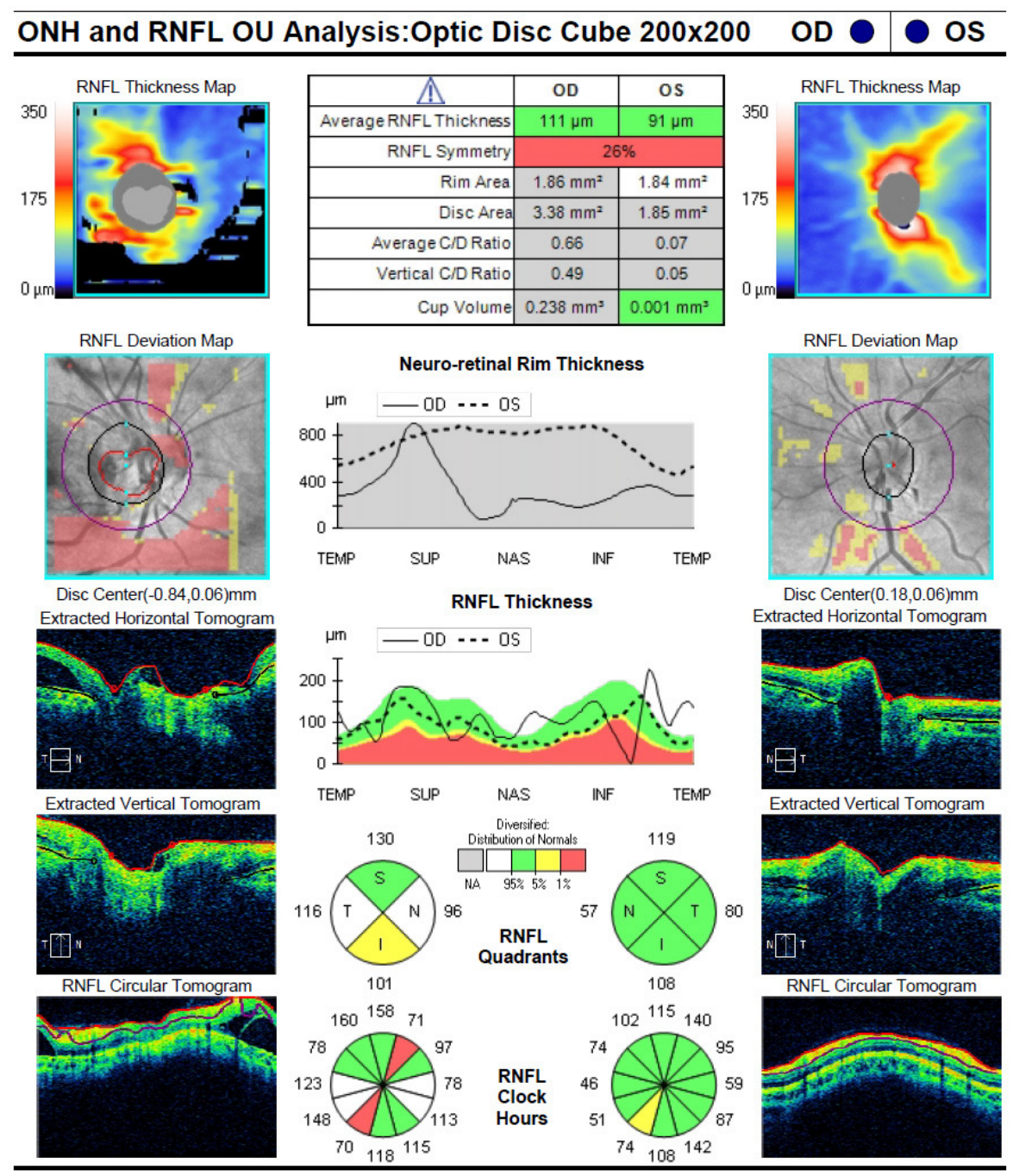

Figure 3. Optic nerve head and retinal nerve fiber layer (RNFL) analysis of the same patient as in Figure 1, showing the RNFL asymmetry between the eyes and the defects of the affected (right) eye that are compatible with an optic disc pit (the Cirrus" HD-OCT Model 400 [Carl Zeiss Meditech, Dublin, CA]).
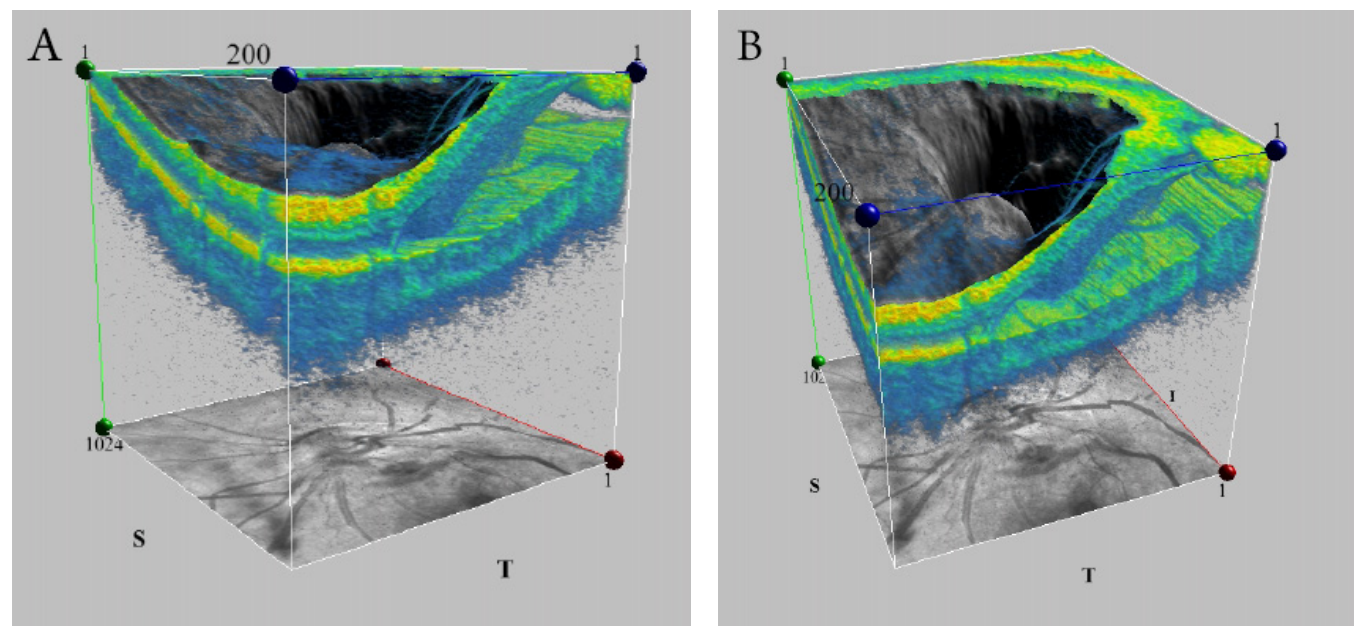

Figure 4 (A, B). Three-dimensional (3D) visualization of the optic disc of the right eye of the same patient as in Figure 1, showing the optic disc pit (ODP). 3D images may be very useful to define the features of ODP in detail and can probably shed more light on the pathogenesis of ODP maculopathy (the Cirrus ${ }^{\mathrm{tw}}$ HD-OCT Model 400 [Carl Zeiss Meditech, Dublin, CA]). 
ETHICAL DECLARATIONS

Ethical approval: This is a review study and no ethical approval was needed. Conflicts of interests: None.

\section{FUNDING}

\section{None.}

\section{ACIKNOWLED GEMENTS}

\section{None.}

\section{REFERENCES}

1. Kalogeropoulos D, Ch'ng SW, Lee R, Elaraoud I, Purohit M, Felicida V, et al. Optic Disc Pit Maculopathy: A Review. Asia Pac J Ophthalmol (Phila). 2019;8(3):247-55. doi: 10.22608/APO.2018473 pmid: 31179667

2. Javitt JC, Spaeth GL, Katz LJ, Poryzees E, Addiego R. Acquired pits of the optic nerve. Increased prevalence in patients with low-tension glaucoma. Ophthalmology. 1990;97(8):1038-43; discussion 43-4. doi: 10.1016/s0161-6420(90)32466-1 pmid: 2402415

3. Ohno-Matsui K, Akiba M, Moriyama M, Shimada N, Ishibashi T, Tokoro T, et al. Acquired optic nerve and peripapillary pits in pathologic myopia. Ophthalmology. 2012;119(8):1685-92. doi: 10.1016/j.ophtha.2012.01.047 pmid: 22494632

4. Radius RL, Maumenee AE, Green WR. Pit-like changes of the optic nerve head in open-angle glaucoma. Br J Ophthalmol. 1978;62(6):389-93. doi: 10.1136/bjo.62.6.389 pmid: 666988

5. Healey PR, Mitchell P. The prevalence of optic disc pits and their relationship to glaucoma. J Glaucoma. 2008;17(1):11-4. doi: 10.1097/IJG.0b013e318133fc34 pmid: 18303377

6. Wang Y, Xu L, Jonas JB. Prevalence of congenital optic disc pits in adult Chinese: The Beijing Eye Study. Eur J Ophthalmol. 2006;16(6):863-4. doi: 10.1177/112067210601600613 pmid: 17191194

7. Radosova V, Krejcirova I, Autrata R, Zajdlikova B. Bilateral Optic Disc Pit with Maculopathy - the Case Report. Cesk Slov Oftalmol. 2019;75(2):86-90. doi: 10.31348/2019/2/5 pmid: 31537077

8. Rossi S, De Rosa G, D'Alterio FM, Orrico A, Banfi S, Testa F, et al. Intrafamilial heterogeneity of congenital optic disc pit maculopathy. Ophthalmic Genet. 2017;38(3):267-72. doi: 10.1080/13816810.2016.1188120 pmid: 27268460

9. Stefko ST, Campochiaro P, Wang P, Li Y, Zhu D, Traboulsi EI. Dominant inheritance of optic pits. Am J Ophthalmol. 1997; 124(1):112 3. doi: 10.1016/s0002-9394(14)71656-3 pmid: 9222245

10. Slusher MM, Weaver RG, Jr., Greven CM, Mundorf TK, Cashwell LF. The spectrum of cavitary optic disc anomalies in a family. Ophthalmology. 1989;96(3):342-7. doi: 10.1016/s0161-6420(89)32886-7 pmid: 2710526

11. Kranenburg EW. Crater-like holes in the optic disc and central serous retinopathy. Arch Ophthalmol. 1960;64:912-24. doi: 10.1001/ archopht. 1960.01840010914013 pmid: 13753957

12. Sugar HS. An explanation for the acquired macular pathology associated with congenital pits of the optic disc. Am J Ophthalmol. 1964 May;57(833-5).pmid: 14167198

13. Sugar HS. Congenital pits in the optic disc and their equivalents (congenital colobomas and colobomalike excavations) associated with submacular fluid. Am J Ophthalmol. 1967 Feb;63(2):298-307. doi: 10.1016/0002-9394(67)91553-X pmid: 4959901

14. Gordon R, Chatfield RK. Pits in the optic disc associated with macular degeneration. Br J Ophthalmol. 1969;53(7):481-9. doi: 10.1136/bjo.53.7.481 pmid: 5804034

15. Brodsky MC. Congenital optic disk anomalies. Surv Ophthalmology. 1994;39(89e112). doi: 10.1016/0039-6257(94)90155-4 pmid: 7801227

16. Kalogeropoulos D, Ch'ng SW, Lee R, Elaraoud I, Felicida V, Purohit M, et al. Optic Disc Pit Maculopathy - Case Series, Clinical Approach, and Management. Middle East Afr J Ophthalmol. 2020;27(1):34-9. doi: 10.4103/meajo.MEAJO 18119 pmid: 32549722

17. Georgalas I, Kouri A, Ladas I, Gotzaridis E. Optic disc pit maculopathy treated with vitrectomy, internal limiting membrane peeling, and air in a 5-year-old boy. Can J Ophthalmol. 2010;45(2):189-91. doi: 10.3129/i09-215 pmid: 20379320

18. Iftikhar M, Shah SMA, Goldberg MF. A Case of Optic Disc Pit Maculopathy Observed without Intervention for 6 Years. Ophthalmol Retina. 2019;3(2):195-7. doi: 10.1016/j.oret.2018.09.019 pmid: 31014772

19. Akca Bayar S, Sarigul Sezenoz A, Yaman Pinarci E, Yilmaz G. Spontaneous Regression of Optic Disc Pit Maculopathy in a Six-Year-Old Child. Turk J Ophthalmol. 2017;47(1):56-8. doi: 10.4274/tjo.57614 pmid: 28182177

20. Yuen CH, Kaye SB. Spontaneous resolution of serous maculopathy associated with optic disc pit in a child: a case report. J AAPOS. 2002;6(5):330-1. doi: 10.1067/mpa.2002.127921 pmid: 12381994

21. Uzel MM, Karacorlu M. Optic disk pits and optic disk pit maculopathy: A review. Surv Ophthalmol. 2019;64(5):595-607. doi: 10.1016/j.survophthal.2019.02.006 pmid: 30797884

22. Theodossiadis G. Evolution of congenital pit of the optic disk with macular detachment in photocoagulated and nonphotocoagulated eyes. Am J Ophthalmol. 1977;84(5):620-31. doi: 10.1016/0002-9394(77)90375-0 pmid: 930990

23. Theodossiadis GP, Theodossiadis PG, Ladas ID, Zafirakis PK, Kollia AC, Koutsandrea C, et al. Cyst formation in optic disc pit maculopathy. Doc Ophthalmol. 1999;97(3-4):329-35. doi: 10.1023/a:1002194324791 pmid: 10896347

24. Steel DHW, Suleman J, Murphy DC, Song A, Dodds S, Rees J. Optic Disc Pit Maculopathy: A Two-Year Nationwide Prospective Population-based Study. Ophthalmology. 2018;125(11):1757-64. doi: 10.1016/j.ophtha.2018.05.009 pmid: 29887331

25. Rii T, Hirakata A, Inoue M. Comparative findings in childhood-onset versus adult-onset optic disc pit maculopathy. Acta Ophthalmol. 2013;91(5):429-33. doi: 10.1111/j.1755-3768.2012.02429.x pmid: 22551388

26. Lincoff H, Yannuzzi L, Singerman L, Kreissig I, Fisher Y. Improvement in visual function after displacement of the retinal elevations emanating from optic pits. Arch Ophthalmol. 1993;111(8):1071-9. doi: 10.1001/archopht.1993.01090080067020 pmid: 8352690

27. Theodossiadis GP, Chatziralli IP, Theodossiadis PG. Macular buckling in optic disc pit maculopathy in association with the origin of macular elevation: 13-year mean postoperative results. Eur J Ophthalmol. 2015;25(3):241-8. doi: 10.5301/ejo.5000553 pmid: 25588593

28. Theodossiadis GP. Treatment of maculopathy associated with optic disk pit by sponge explant. Am J Ophthalmol. 1996;121(6):630-7. doi: 10.1016/s0002-9394(14)70628-2 pmid: 8644805 
29. Theodossiadis GP, Theodossiadis PG. The macular buckling technique in the treatment of optic disk pit maculopathy. Semin Ophthalmol. 2000;15(2):108-15. doi: 10.3109/08820530009040001 pmid: 11309743

30. Theodossiadis GP, Theodossiadis PG. Optical coherence tomography in optic disk pit maculopathy treated by the macular buckling procedure. Am J Ophthalmol. 2001;132(2):184-90. doi: 10.1016/s0002-9394(01)00997-7 pmid: 11476677

31. Brockhurst RJ. Optic pits and posterior retinal detachment. Trans Am Ophthalmol Soc. 1975;73:264-91. pmid: 1246808

32. Theodossiadis GP, Panopoulos M, Kollia AK, Georgopoulos G. Long-term study of patients with congenital pit of the optic nerve and persistent macular detachment. Acta Ophthalmol (Copenh). 1992;70(4):495-505. doi: 10.1111/j.1755-3768.1992.tb02120.x pmid: 1414295

33. Brown GC, Shields JA, Goldberg RE. Congenital pits of the optic nerve head. II. Clinical studies in humans. Ophthalmology. 1980;87(1):51-65. doi: 10.1016/s0161-6420(80)35278-0 pmid: 7375086

34. Chatziralli I, Theodossiadis P, Theodossiadis GP. Optic disk pit maculopathy: current management strategies. Clin Ophthalmol. 2018;12:1417-22. doi: 10.2147/OPTH.S153711 pmid: 30127591

35. Asensio Sanchez VM, Corral Azor A, Bartolome Aragon A, De Paz Garcia M. [Renal-coloboma syndrome]. Arch Soc Esp Oftalmol. 2002;77(11):635-8. pmid: 12410411

36. Caprioli J, Lesser RL. Basal encephalocele and morning glory syndrome. Br J Ophthalmol. 1983;67(6):349-51. doi: 10.1136/ bjo.67.6.349 pmid: 6849854

37. Fea A, Grosso A, Rabbione M, Grignolo F. Alagille syndrome and optic pit. Graefes Arch Clin Exp Ophthalmol. 2007;245(2):315-7. doi: 10.1007/s00417-006-0340-4 pmid: 16673137

38. Kim BJ, Fulton AB. The genetics and ocular findings of Alagille syndrome. Semin Ophthalmol. 2007;22(4):205-10. doi: 10.1080/08820530701745108 pmid: 18097983

39. Pollock JA, Newton TH, Hoyt WF. Transsphenoidal and transethmoidal encephaloceles. A review of clinical and roentgen features in 8 cases. Radiology. 1968;90(3):442-53. doi: 10.1148/90.3.442 pmid: 4966739

40. Jain N, Johnson MW. Pathogenesis and treatment of maculopathy associated with cavitary optic disc anomalies. Am J Ophthalmol. 2014;158(3):423-35. doi: 10.1016/j.ajo.2014.06.001 pmid: 24932988

41. Georgalas I, Ladas I, Georgopoulos G, Petrou P. Optic disc pit: a review. Graefes Arch Clin Exp Ophthalmol. 2011;249(8):1113-22. doi: 10.1007/s00417-011-1698-5 pmid: 21638030

42. Lincoff H, Lopez R, Kreissig I, Yannuzzi L, Cox M, Burton T. Retinoschisis associated with optic nerve pits. Retina. 2012;32 Suppl 1:61-7. doi: 10.1097/iae.0b013e31823f9abb pmid: 22451950

43. Krivoy D, Gentile R, Liebmann JM, Stegman Z, Rosen R, Walsh JB, et al. Imaging congenital optic disc pits and associated maculopathy using optical coherence tomography. Arch Ophthalmol. 1996;114(2):165-70. doi: 10.1001/archopht.1996.01100130159008 pmid: 8573019

44. Rutledge BK, Puliafito CA, Duker JS, Hee MR, Cox MS. Optical coherence tomography of macular lesions associated with optic nerve head pits. Ophthalmology. 1996;103(7):1047-53. doi: 10.1016/s0161-6420(96)30568-x pmid: 8684793

45. Roy R, Waanbah AD, Mathur G, Raman R, Sharma T. Optical coherence tomography characteristics in eyes with optic pit maculopathy. Retina. 2013;33(4):771-5. doi: 10.1097/IAE.0b013e31826f5234 pmid: 23423154

46. Theodossiadis G, Theodossiadis P, Chatziralli I. Thoughts and Challenges for the Current Treatment of Optic Disc Pit Maculopathy. Semin Ophthalmol. 2020;35(4):232-6. doi: 10.1080/08820538.2020.1809684 pmid: 32809892

47. Jeng-Miller KW, Cestari DM, Gaier ED. Congenital anomalies of the optic disc: insights from optical coherence tomography imaging. Curr Opin Ophthalmol. 2017;28(6):579-86. doi: 10.1097/ICU.0000000000000425 pmid: 28817389

48. Steel DH, Williamson TH, Laidlaw DA, Sharma P, Matthews C, Rees J, et al. Extent and Location of Intraretinal and Subretinal Fluid as Prognostic Factors for the Outcome of Patients with Optic Disk Pit Maculopathy. Retina. 2016;36(1):110-8. doi: 10.1097/ IAE.0000000000000658 pmid: 26166800

49. Ooto S, Mittra RA, Ridley ME, Spaide RF. Vitrectomy with inner retinal fenestration for optic disc pit maculopathy. Ophthalmology. 2014;121(9):1727-33. doi: 10.1016/j.ophtha.2014.04.006 pmid: 24837239

50. Rosenthal G, Bartz-Schmidt KU, Walter P, Heimann K. Autologous platelet treatment for optic disc pit associated with persistent macular detachment. Graefes Arch Clin Exp Ophthalmol. 1998;236(2):151-3. doi: 10.1007/s004170050056 pmid: 9498127

51. Ozdek S, Ozdemir HB. A New Technique with Autologous Fibrin for the Treatment of Persistent Optic Pit Maculopathy. Retin Cases Brief Rep. 2017;11(1):75-8. doi: 10.1097/ICB.0000000000000293 pmid: 26982208

52. Todorich B, Sharma S, Vajzovic L. Successful Repair of Recurrent Optic Disk Pit Maculopathy with Autologous Platelet Rich Plasma: Report of a Surgical Technique. Retin Cases Brief Rep. 2017;11(1):15-7. doi: 10.1097/ICB.0000000000000276 pmid: 26829447

53. Inoue $\mathrm{M}$, Shinoda $\mathrm{K}$, Ishida S. Vitrectomy combined with glial tissue removal at the optic pit in a patient with optic disc pit maculopathy: a case report. J Med Case Rep. 2008;2:103. doi: 10.1186/1752-1947-2-103 pmid: 18394198

54. Kalogeropoulos D, Kalogeropoulos C, Moschos MM, Sung V. The Management of Uveitic Glaucoma in Children. Turk J Ophthalmol. 2019;49(5):283-93. doi: 10.4274/tjo.galenos.2019.36589 pmid: 31650812

55. Theodossiadis PG, Grigoropoulos VG, Emfietzoglou J, Theodossiadis GP. Vitreous findings in optic disc pit maculopathy based on optical coherence tomography. Graefes Arch Clin Exp Ophthalmol. 2007;245(9):1311-8. doi: 10.1007/s00417-007-0534-4 pmid: 17285337

56. Shukla D, Kalliath J, Tandon M, Vijayakumar B. Vitrectomy for optic disk pit with macular schisis and outer retinal dehiscence. Retina. 2012;32(7):1337-42. doi: 10.1097/IAE.0b013e318235d8fc pmid: 22481474

57. Rizzo S, Belting C, Genovesi-Ebert F, Di Bartolo E, Cresti F, Cinelli L, et al. Optic disc pit maculopathy: the value of small-gauge vitrectomy, peeling, laser treatment, and gas tamponade. Eur J Ophthalmol. 2012;22(4):620-5. doi: 10.5301/ejo.5000083 pmid: 22081669

58. Maertz J, Mohler KJ, Kolb JP, Kein T, Neubauer A, Kampik A, et al. Intrapapillary proliferation in optic disk pits: Clinical findings and time-related changes. Retina. 2017;37(5):906-14. doi: 10.1097/IAE.0000000000001260 pmid: 27617535

59. Yokoi T, Nakayama Y, Nishina S, Azuma N. Abnormal traction of the vitreous detected by swept-source optical coherence tomography is related to the maculopathy associated with optic disc pits. Graefes Arch Clin Exp Ophthalmol. 2016;254(4):675-82. doi: 10.1007/ s00417-015-3114-z pmid: 26245337

60. Rayat JS, Rudnisky CJ, Waite C, Huang P, Sheidow TG, Kherani A, et al. Long-Term Outcomes for Optic Disk Pit Maculopathy after Vitrectomy. Retina. 2015;35(10):2011-7. doi: 10.1097/IAE.0000000000000576 pmid: 25923958

61. Lei L, Li T, Ding X, Ma W, Zhu X, Atik A, et al. Gas tamponade combined with laser photocoagulation therapy for congenital optic disc pit maculopathy. Eye (Lond). 2015;29(1):106-14. doi: 10.1038/eye.2014.245 pmid: 25323852

62. Hiraoka T, Inoue M, Ninomiya Y, Hirakata A. Infrared and fundus autofluorescence imaging in eyes with optic disc pit maculopathy. Clin Exp Ophthalmol. 2010;38(7):669-77. doi: 10.1111/j.1442-9071.2010.02311.x pmid: 20456431

63. Benatti E, Garoli E, Viola F. Spontaneous Resolution of Optic Disk Pit Maculopathy in a Child after a Six-Year Follow-Up. Retin Cases Brief Rep. 2021;15(4):453-6. doi: 10.1097/ICB.0000000000000815 pmid: 30086106 
64. Ozkaya A, Alkin Z, Taylan AT, Demirok A. Ocular imaging findings of bilateral optic disc pit in a child. Nepal J Ophthalmol. 2013;5(2):258-61. doi: 10.3126/nepjoph.v5i2.8739 pmid: 24172565

65. Brodsky MC. Congenital optic pit with serous maculopathy in childhood. J AAPOS. 2003;7(2):150; author reply doi: 10.1016/s10918531(03)00008-9 pmid: 12756987

66. Bloch E, Georgiadis O, Lukic M, da Cruz L. Optic Disc Pit Maculopathy: New Perspectives on the Natural History. Am J Ophthalmol. 2019;207:159-69. doi: 10.1016/j.ajo.2019.05.010 pmid: 31095956

67. Kováčová M, Meliška M, Kalvodová B. OCT Findings and Long-term Follow-up Results of Vitrectomy in Patients with Optic Disc Pit and Associated Maculopathy. Cesk Slov Oftalmol. 2018 Spring;73(5-6):171-7. English. pmid: 30541296

68. Mete A, Turkcuoglu P, Kimyon S, Gungor K. The results of 25-gauge vitreoretinal surgery for optic disc pit-associated maculopathy: a report of three cases and mini-review of the literature. Int Ophthalmol. 2017;37(4):1057-63. doi: 10.1007/s10792-016-0336-y pmid: 27614461

69. Akiyama H, Shimoda Y, Fukuchi M, Kashima T, Mayuzumi H, Shinohara Y, et al. Intravitreal gas injection without vitrectomy for macular detachment associated with an optic disk pit. Retina. 2014;34(2):222-7. doi: 10.1097/IAE.0b013e3182993d93 pmid: 23873162

70. Sanghi G, Padhi TR, Warkad VU, Vazirani J, Gupta V, Dogra MR, et al. Optical coherence tomography findings and retinal changes after vitrectomy for optic disc pit maculopathy. Indian J Ophthalmol. 2014;62(3):287-90. doi: 10.4103/0301-4738.111191 pmid: 23619493

71. Marticorena J, Gomez-Ulla F, Romano MR, Fernandez M. Dye-guided retinal laser and internal drainage for optic pit maculopathy. Graefes Arch Clin Exp Ophthalmol. 2013;251(1):381-2. doi: 10.1007/s00417-011-1828-0 pmid: 21964822

72. Hirakata A, Inoue M, Hiraoka T, McCuen BW, 2nd. Vitrectomy without laser treatment or gas tamponade for macular detachment associated with an optic disc pit. Ophthalmology. 2012;119(4):810-8. doi: 10.1016/j.ophtha.2011.09.026 pmid: 22218142

73. Imamura Y, Zweifel SA, Fujiwara T, Freund KB, Spaide RF. High-resolution optical coherence tomography findings in optic pit maculopathy. Retina. 2010;30(7):1104-12. doi: 10.1097/IAE.0b013e3181d87ecb pmid: 20523264

74. Chiu YT, Chen HY, Tsai YY, Lin JM, Chiang CC. Stratus optical coherence tomography for evaluating optic disc pits associated with maculopathy before and after vitrectomy: two case reports. Kaohsiung J Med Sci. 2006;22(5):229-34. doi: 10.1016/S1607551X(09)70241-4 pmid: 16793558

75. Spaide RF, Fisher Y, Ober M, Stoller G. Surgical hypothesis: inner retinal fenestration as a treatment for optic disc pit maculopathy. Retina. 2006;26(1):89-91. doi: 10.1097/00006982-200601000-00014 pmid: 16395144

76. Ishikawa K, Terasaki H, Mori M, Sugita K, Miyake Y. Optical coherence tomography before and after vitrectomy with internal limiting membrane removal in a child with optic disc pit maculopathy. Jpn J Ophthalmol. 2005;49(5):411-3. doi: 10.1007/s10384-004-0225-1 pmid: 16187043

77. Hirakata A, Hida T, Wakabayashi T, Fukuda M. Unusual posterior hyaloid strand in a young child with optic disc pit maculopathy: intraoperative and histopathological findings. Jpn J Ophthalmol. 2005;49(3):264-6. doi: 10.1007/s10384-004-0185-5 pmid: 15944837

78. Bakri SJ, Beer PM. Vitreoretinal surgery for optic pit associated serous macular detachment: a discussion of two cases. Int Ophthalmol. 2004;25(3):143-6. doi: 10.1007/s10792-004-5197-0 pmid: 15847312

79. Meyer CH, Rodrigues EB. Optic disc pit maculopathy after blunt ocular trauma. Eur J Ophthalmol. 2004;14(1):71-3. doi: 10.1177/112067210401400114 pmid: 15005591 